\title{
Microbiological treatment system of storage ponds
}

\author{
Olga Kovaleva $^{1, *}$, Natalia Sannikova ${ }^{1}$ \\ ${ }^{1}$ Northern Trans-Ural State Agricultural University, Respubliki str. 7, Tyumen, 625003, Russia
}

\begin{abstract}
One of the main sources of water pollution is industry, including food production enterprises. Wastewater of this industry is intensively polluted with easily decomposable organic substances, which can cause great damage to water bodies. Existing wastewater treatment technologies are extremely energy-consuming due to deficiencies in the analysis of the composition of liquid media, which can reveal an excess of maximum permissible concentrations of not more than ten percent of the total amount of normalized pollution. In the present paper, data on the existing wastewater discharge obtained by the laboratory method are presented, and the level of their pollution is estimated. Information about the developed Microbiological Treatment System and its ability to reduce pollutant concentrations is presented: for suspended solids by 17 times, for mass concentration of fats by 17 times, for BOD5 (biochemical oxygen demand) by 45 times, for COD (chemical oxygen demand) by 10 times, in artificially created storage ponds.
\end{abstract}

\section{Introduction}

In most rural areas, an acute environmental situation has arisen, which was facilitated by the intensification of agricultural production [1, 2], the development of processing enterprises, its low technological level, as well as the shortcomings of the regulatory framework in this direction.

Wastewater treatment of industrial enterprises in Russia has been given close attention since 1885. Further, including at present, serious attention is paid to the development of wastewater treatment methods, in particular biological methods.

For pre-treatment or neutralization of extremely contaminated wastewater, technological plants must have special local treatment installations, but many enterprises that were commissioned 20-35 years ago do not have them, and, in the worst case, are forced to drain the sewage into artificially created storage ponds.

Effective, but expensive methods can be used: reverse osmosis, nanofiltration, electrocoagulation and others. However, the economic condition of many rural entities of the Russian Federation limits the resource opportunities for the implementation of environmental activities.

Constantly increasing volumes of wastewater, an increasing number of types and degree of pollution significantly complicate the solution of issues of minimizing environmental

\footnotetext{
Corresponding author: lemur.84@mail.ru
} 
risks, ecological management in the regions [3-5]. Issues of improving the wastewater treatment system, its functioning in the presence of large processing plants require further study and generalization.

Currently, there are no data in the literature that show how the bacilli properties change depending on the nature of the aquatic environment pollution, which is of great interest for research. Bacteria of the genus Bacillus are ubiquistic, that is, ubiquitous. Due to their ability to sporulate, bacteria of the genus Bacillus can survive in extreme environmental conditions, as well as be resistant to various chemicals, various physical factors, including wet steam, drying, ultraviolet and gamma radiation, vacuum and oxidizing agents.

The introduction of microbiological treatment technologies into production processes $[6,7]$, wastewater treatment, and treatment of other biological environmentally harmful production wastes is today an advanced scientific field that uses nature-like technologies. The aim of this work was to develop and test the technology of the Microbiological Treatment System (MBTS) during the rehabilitation of artificially created sewage ponds for a milk processing enterprise.

\section{$2 \quad$ Materials and Methods}

A feature of MBTS is the introduction of microbiological preparations into the wastewater according to an individually developed technology, that are safe for ecosystems, since their work is based on natural biological reactions and not on the use of chemical compounds. When using MBTS, the effect can be observed after 2-4 months.

The object of research was the storage ponds located in the local forestry, intended for the accumulation of wastewater from the food industry plant. These objects are closed-type storages and artificially created. They have a rectangular shape ranging from $1575 \mathrm{~km}^{2}$ to $1625 \mathrm{~km}^{2}$ and are surrounded by a bulk dam $3.0 \mathrm{~m}$ wide around the perimeter. Flora of the adjacent territory of storage ponds is represented by the following types of vegetation: urtica dioica, atriplex patula, cirsium arvense, sonchus arvensis, elytrigia repens, tussilago, barbarea vulgaris, salix acutifolia, prunus padus, acer platanoides, bromus inermis, betula pendula, equisetum arvense, pinus sylvestris, epilobium, arctium.

As a microbiological rehabilitation of existing storage ponds, a probiotic preparation was chosen as the basis, which is a liquid containing a large number of bacteria of the genus BACILLUS, which are representatives of obligate microflora [8, 9].

According to the results of a model experiment in laboratory conditions, the optimal concentration of the microbiological preparation for use in real conditions was established and the Microbiological Treatment System for the rehabilitation of storage ponds was proposed.

The preparation of the microbiological preparation consisted in the production of the stock solution. For the first 3 days, $0.5 \mathrm{~kg}$ of carbohydrates were added to a cesspool machine for 5 tons of water $\left(t=+35^{\circ} \mathrm{C}\right)$ and 100 liters of concentrated microbiological preparation were poured. The next 10 days, $0.5 \mathrm{~kg}$ of carbohydrates were added to a cesspool machine for 5 tons of water $\left(\mathrm{t}=+35^{\circ} \mathrm{C}\right)$ and 50 liters of a concentrated solution of a microbiological preparation were poured. The preparation time for the stock solution before it was introduced into the storage pond was 1 hour, with constant stirring. The prepared solution was evenly distributed over the area of the storage pond using a perforated hose. For the effective operation of bacteria, aeration was performed by the compressor. Aeration was carried out for 30 minutes 3 times a day.

For the most efficient operation of bacteria of the genus Bacillus, it is necessary to comply with the requirements for the temperature regime of water and the hydrogen index $(\mathrm{pH})$. In warm water $\left(+36^{\circ} \mathrm{C}\right)$, the processes of dividing on spores begin. The necessary 
enzymes are secreted, the bacteria divide, increasing their numbers. Bacteria consume an organic substrate and turn it into $\mathrm{CO}_{2}$, purifying the water system naturally.

When preparing the working solution, the temperature of the water in the tank varied from 30 to $36^{\circ} \mathrm{C}$.

When conducting scientific and industrial research, monthly wastewater sampling was carried out in the period from July to September according to GOST 31861-2012, GOST 31862-2012, GOST 17.1.5.05-85. Chemical analysis was carried out according to 6 main indicators according to (normative documents per test method): suspended solids (Guidance Document 52.24.468-2005), ammonium nitrogen (GOST 29304), phosphates (GOST 18309), $\mathrm{BOD}_{5}$ (Federal Environmental Regulation 14.1:2:3:4.123), COD (Federal Environmental Regulation 14.1:2:4.190), mass concentration of fats (Federal Environmental Regulation 14.1:2.122).

\section{Results/Discussion}

At the enterprise, water is used for: boiler room operation (heating and steam generation); production and technological needs; household needs. Water supply of the enterprise is carried out from the village water supply. Wastewater during the operation of the enterprise is generated in a volume of $289 \mathrm{~m}^{3} /$ day $\left(105485 \mathrm{~m}^{3} /\right.$ year), which contains detergent and disinfectant solutions $\left(\mathrm{NaOH}, \mathrm{HNO}_{3}\right)$. As a result of milk processing processes, technological wastewater is also formed, characterized by high (over $1000 \mathrm{mg} / \mathrm{l}$ ) contamination by biodegradable organic substances, primarily fats, proteins and carbohydrates. Pollution increases many times [10-12], because the enterprise has not solved the problem of recycling production waste, primarily whey. The enterprise discharges waste water through an in-depth sewage system into an underground reinforced concrete sump and then is transported to the storage pond by cars. Dumping is carried out all year round.

At the studied object, an excess of indicators was noted in comparison with the hygienic standard, which served as the basis for conducting scientific and production experiments in order to reduce the environmental load on the environment.

Table 1 Hydrochemical parameters of the storage pond

\begin{tabular}{|l|c|c|}
\hline \multicolumn{1}{|c|}{ Indicator } & Hygiene standard* & Actual result \\
\hline $\mathrm{pH}$ & $6.0-9.0$ & 5.7 \\
\hline Suspended matter, $\mathrm{mg} / \mathrm{dm}^{3}$ & 300.0 & 462.5 \\
\hline $\mathrm{COD}, \mathrm{mg} / \mathrm{dm}^{3}$ & 500.0 & 12325.0 \\
\hline $\mathrm{BOD}_{5}, \mathrm{mg} / \mathrm{dm}^{3}$ & 300.0 & 6870.0 \\
\hline Nitrates, $\mathrm{mg} / \mathrm{dm}^{3}$ & 45.0 & 11.0 \\
\hline Nitrites, $\mathrm{mg} / \mathrm{dm}^{3}$ & 3.3 & 0.46 \\
\hline Phosphates, $\mathrm{mg} / \mathrm{dm}^{3}$ & 12.0 & 6.53 \\
\hline Fats, $\mathrm{mg} / \mathrm{dm}^{3}$ & 50.0 & 126.0 \\
\hline Ammonium nitrogen, $\mathrm{mg} / \mathrm{dm}^{3}$ & 1.5 & 6.4 \\
\hline
\end{tabular}

* - Decree of the Government of the Russian Federation of July 29, 2013 No. 644 "Rules for cold water supply and sanitation"

The company regularly carries out cleaning of the sump from trapped suspended solids. Indicators of changes in the wastewater composition of the enterprise in the collector are 
presented in Table 2 (according to laboratory studies during the day).

Table 2 Composition of the wastewater in the collector

\begin{tabular}{|l|c|c|c|c|}
\hline \multirow{2}{*}{ Indicator } & \multicolumn{4}{|c|}{$\begin{array}{c}\text { The value of the indicator in three parallel measurements, the } \\
\text { average value and the absolute error of direct measurement }\end{array}$} \\
\cline { 2 - 5 } & $\begin{array}{c}\text { Sample No.1 } \\
9-45\end{array}$ & $\begin{array}{c}\text { Sample No.2 } \\
11-00\end{array}$ & $\begin{array}{c}\text { Sample No.3 } \\
14-00\end{array}$ & $\begin{array}{c}\text { Sample No.4 } \\
18-00\end{array}$ \\
\hline $\mathrm{pH}$ & $5.72 \pm 0.00$ & $5.16 \pm 0.00$ & $4.72 \pm 0.01$ & $6.17 \pm 0.00$ \\
\hline Suspended matter, mg/l & $662.6 \pm 6.4$ & $1143 \pm 38$ & $9947 \pm 63$ & $729.5 \pm 31.8$ \\
\hline $\mathrm{COD}, \mathrm{mgO} / \mathrm{l}$ & $2777 \pm 14$ & $5020 \pm 433$ & $7860 \pm 347$ & $3113 \pm 287$ \\
\hline $\mathrm{BOD}_{5}, \mathrm{mgO} / \mathrm{l}$ & $1204 \pm 133$ & $1932 \pm 31$ & $3626 \pm 155$ & $\begin{array}{c}\text { Not } \\
\text { measured }\end{array}$ \\
\hline Solids, mg/l & $2050 \pm 107$ & $2268 \pm 285$ & $2341 \pm 5$ & $\begin{array}{c}1033.5 \pm 115 . \\
7\end{array}$ \\
\hline Total iron, mg/l & $0.2 \pm 0.01$ & $1.12 \pm 0.07$ & $0.82 \pm 0.01$ & $2.53 \pm 0.00$ \\
\hline NH, $\mathrm{mg} / \mathrm{l}$ & $20.9 \pm 1.27$ & $12.69 \pm 0.13$ & $\begin{array}{c}\text { Not } \\
\text { measured }\end{array}$ & $13.51 \pm 0.13$ \\
\hline Phosphates, mg/l & $90.65 \pm 0.64$ & $147.25 \pm 0.64$ & $675.9 \pm 1.27$ & $\begin{array}{c}\text { Not } \\
\text { measured }\end{array}$ \\
\hline Fats, mg/l & Not measured & $66.35 \pm 4.45$ & $825 \pm 57$ & $22.5 \pm 3.7$ \\
\hline Petroleum products, mg/l & Not measured & $\begin{array}{c}\text { Not } \\
\text { measured }\end{array}$ & $6.67 \pm 0.07$ & $18.1 \pm 0.64$ \\
\hline
\end{tabular}

The contamination of these sumps significantly exceeds the requirements for wastewater into the sewage system of a settlement. The high concentration of this type of wastewater, as well as the unevenness of their flow, lead to the overload of many urban wastewater treatment plants and its unsatisfactory performance.

As a result of a model experiment in laboratory conditions, the optimal concentration of the microbiological preparation was established. The dynamics of hydrochemical parameters in a model experiment are shown in Table 3.

Table 3. Dynamics of hydrochemical parameters in a model experiment

\begin{tabular}{|l|c|c|c|c|}
\hline \multirow{2}{*}{ Indicators } & Initial values & \multicolumn{3}{|c|}{ Concentration of the stock solution } \\
\cline { 3 - 5 } & 1400 & $0,1 \%$ & $0,01 \%$ & $0,001 \%$ \\
\hline $\begin{array}{l}\text { Suspended matter, } \\
\mathrm{mg} / \mathrm{dm}^{3}\end{array}$ & 300 & 1300 & 990 & 440 \\
\hline $\begin{array}{l}\mathrm{Ammonium} \text { nitrogen, } \\
\mathrm{mg} / \mathrm{dm}^{3}\end{array}$ & 100 & 100 & 100 \\
\hline $\mathrm{Phosphates,} \mathrm{mg} / \mathrm{dm}^{3}$ & 64.44 & 20.76 & 18.25 & 15.34 \\
\hline $\mathrm{BOD}_{5}, \mathrm{mgO}_{2} / \mathrm{dm}^{3}$ & $931 \pm 84$ & $300 \pm 27$ & $440 \pm 40$ & $280 \pm 25$ \\
\hline $\mathrm{COD}, \mathrm{mgO}_{2} / \mathrm{dm}^{3}$ & $1803 \pm 298$ & $961 \pm 134$ & $1034 \pm 145$ & $727 \pm 102$ \\
\hline $\begin{array}{l}\text { Mass concentration of } \\
\text { fats, } \mathrm{mg} / \mathrm{dm}^{3}\end{array}$ & $20.6 \pm 1.6$ & $3.8 \pm 0.3$ & $5.3 \pm 0.7$ & $7.6 \pm 1.1$ \\
\hline
\end{tabular}

The results of a performed model experiment indicate a significant decrease in the content of all substances. In this case, the best values were noted with the concentration of the stock solution $0.001 \%$.

The results of the analysis of wastewater samples during the rehabilitation of storage ponds are presented in Table 4. According to the results of studies, it was noted that the concentration of the following pollutants decreased from July to September: for suspended 
solids by 17 times, for mass fat concentration by 17 times, for $\mathrm{BOD}_{5}$ by 45 times, for COD by 10 times, which corresponds to the indicators of hygienic standards.

Table 4. Results of the analysis of wastewater storage pond

\begin{tabular}{|l|c|c|c|c|}
\hline \multirow{2}{*}{ Indicators } & \multicolumn{3}{|c|}{ Month of sampling } & \multirow{2}{*}{$\begin{array}{c}\text { Hygienic } \\
\text { standard }\end{array}$} \\
\cline { 2 - 4 } & July & August & September & \\
\hline Suspended matter, $\mathrm{mg} / \mathrm{dm}^{3}$ & 1400.0 & 130.0 & 79 & 300.0 \\
\hline Ammonium nitrogen, $\mathrm{mg} / \mathrm{dm}^{3}$ & 300.0 & 100.0 & $>50$ & 1.5 \\
\hline Phosphates, $\mathrm{mg} / \mathrm{dm}^{3}$ & 64.44 & 32.97 & 65.3 & 12.0 \\
\hline $\mathrm{BOD}_{5,} \mathrm{mgO}_{2} / \mathrm{dm}^{3}$ & $931 \pm 84$ & $742 \pm 100$ & 20.5 & 300.0 \\
\hline $\mathrm{COD}, \mathrm{mgO}_{2} / \mathrm{dm}^{3}$ & $\begin{array}{c}1803 \pm \\
298\end{array}$ & $790 \pm 118$ & 176 & 500.0 \\
\hline $\begin{array}{l}\text { Mass concentration of fats, } \\
\text { mg/dm }\end{array}$ & $\begin{array}{c}20.6 \pm \\
1.6\end{array}$ & $12.2 \pm 1.7$ & $1.2 \pm 0.22$ & 50.0 \\
\hline
\end{tabular}

According to the results of studies, an increase in the content of ammonium nitrogen was noted, which is associated with the activity of bacteria that decompose organic compounds in water. In this case, it is possible that protein compounds decompose under the action of a high concentration of bacteria with the formation of ammonium nitrogen in anaerobic zones (which are always present).

Phosphates steadily increased during the experiment. Basically, it can be assumed that the presence of phosphates in wastewater is caused by the death of activated sludge biomass cells at any stage of biological oxidation [13-15]. The explanation of these data requires further research.

The pollution in the storage pond was reduced due to the vital activity of the introduced microorganisms [16], as well as zooplankton, which is intensively developing directly in the pond itself due to the formation of a large number of biogens. The increase in the number of algae intensified the process of oxygen exchange, which positively affected the vital activity of microorganisms. In addition, oxygen was supplied not only through the free surface due to natural, but also artificial daily aeration, thermal mass transfer (pond depth $0.6 \ldots 1.4 \mathrm{~m})$. A correctly selected hydraulic regime of fluid flow in the storage pond (exclusion of stagnant zones) has improved the conditions for the transfer of oxygen into the water column. In turn, the presence of oxygen improved the oxidation of the biodegradable substrate.

Figure 1 shows the results of a change in the state of the storage pond from July to September. A significant change was noted not only in hydrochemical indicators, but also in terms of color, turbidity of the storage pond effluent. There was also a change in its aesthetic state, including due to the mechanical cleaning of the storage pond.

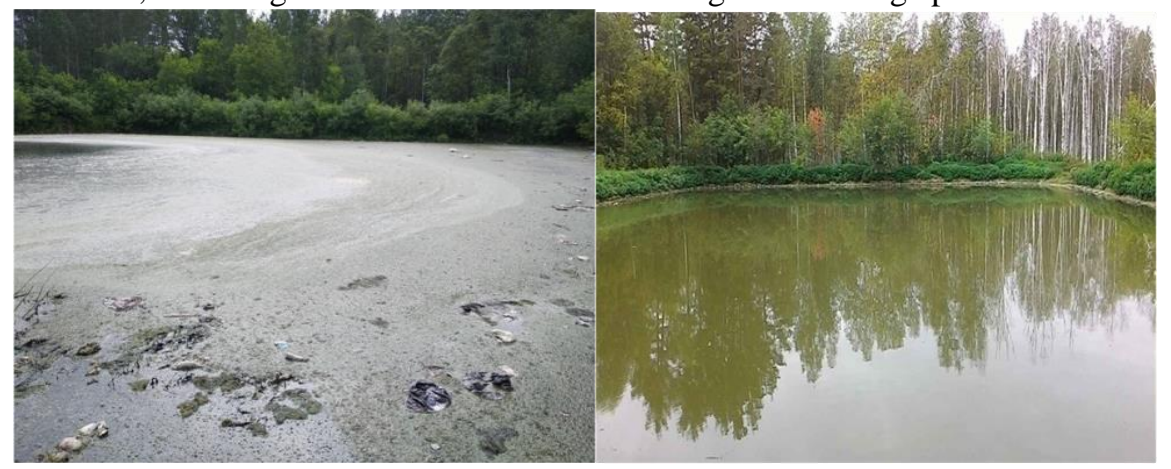

Fig. 1. Change in the status of storage ponds 
According to the results of industrial studies, a change in wastewater by smell was noted. The smell from a very strong (5 points) on the first day of observations gradually decreased to a noticeable ( 3 points) and weak ( 2 points), which indirectly indicates a decrease in the emission of toxic gases (ammonia, hydrogen sulfide) from the wastewater. The smell on the scale is sulphurous, the type of smell is rotten eggs, hydrogen sulfide. The smell changed over time to the smell of natural origin.

Smell intensity is influenced by temperature, $\mathrm{pH}$, the degree of contamination of the pond, the biological environment and hydrological conditions.

The color of the water in the pond was characterized by brown to light brown and practically did not change during the experiment. After removal of the film, some clarification of the water was observed (up to $5 \mathrm{~cm}$ ), which is due to a decrease in suspension.

After a year, after the introduction of the microbiological treatment system, additional studies of the state of storage ponds were carried out. The experimental storage pond is shown in Figure 2.


Fig. 2. Condition of storage ponds in a year

The dynamics of sanitary-hygienic indicators of storage ponds is presented in Table 5, Fig. 2. During microbiological treatment with a probiotic preparation, the environmental effects of pollution and eutrophication of the pond are effectively neutralized, biological equilibrium is restored, water and bottom sediments are cleaned of organic residues, suspended solids, nitrogen, phosphorus, the oxygen regime is restored, the level of bottom sediments decreases, silted springs open, microbiological self-treatment of water from harmful microorganisms intensifies many times. 
Table 5. Dynamics of the sanitary-hygienic indicators of storage ponds

\begin{tabular}{|c|c|c|c|c|c|c|c|}
\hline \multirow{2}{*}{ Indicator } & \multicolumn{3}{|c|}{ Storage pond (experience) } & \multicolumn{2}{|c|}{$\begin{array}{l}\text { Storage pond } \\
\text { (control) }\end{array}$} & \multirow{2}{*}{$\begin{array}{l}\text { Indicators of a } \\
\text { natural reservoir }\end{array}$} & \multirow{2}{*}{$\begin{array}{l}\text { Hygienic } \\
\text { standard* }\end{array}$} \\
\hline & $\begin{array}{l}\text { before the } \\
\text { start of the } \\
\text { experiment } \\
(2018)\end{array}$ & 2018 & 2019 & 2018 & 2019 & & \\
\hline $\begin{array}{l}\text { Suspended matter, } \\
\mathrm{mg} / \mathrm{dm}^{3}\end{array}$ & 462.5 & 79 & 140 & 68 & 120 & $3-14$ & 300.0 \\
\hline $\mathrm{COD}, \mathrm{mg} / \mathrm{dm}^{3}$ & 12325 & 176 & 174 & 201 & 468 & $\begin{array}{l}\text { from fractions to } \\
\text { tens of } \mathrm{mg}\end{array}$ & 500.0 \\
\hline $\mathrm{BOD}_{5}, \mathrm{mg} / \mathrm{dm}^{3}$ & 68700 & 20.5 & 57 & 25.2 & 254 & $0.5-4$ & 300.0 \\
\hline Phosphates, $\mathrm{mg} / \mathrm{dm}^{3}$ & 6.53 & 65.3 & 13 & 47.5 & 28 & $0.005-0.2$ & 12.0 \\
\hline Fats, $\mathrm{mg} / \mathrm{dm}^{3}$ & 126 & 1.2 & 14.7 & 0.8 & 512 & $\begin{array}{c}\text { from hundredths } \\
\text { to several mg }\end{array}$ & 50.0 \\
\hline $\begin{array}{l}\text { Ammonium nitrogen, } \\
\mathrm{mg} / \mathrm{dm}^{3}\end{array}$ & 6.4 & $>50$ & 37.1 & $>50$ & 6.6 & $0.28-0.3$ & 1.5 \\
\hline
\end{tabular}

* - Decree of the Government of the Russian Federation of July 29, 2013 No. 644 "Rules for cold water supply and sanitation"

\section{Conclusion}

It was established that the use of the Microbiological Treatment System allowed reducing concentrations: for suspended solids by 17 times, for mass concentration of fats by 17 times, for $\mathrm{BOD}_{5}$ by 45 times, for COD by 10 times, which corresponds to the indicators of the hygiene standard. In addition, the use of MBTS can significantly reduce the intensity of the smell, which can indirectly indicate a decrease in the release of toxic gases (ammonia, hydrogen sulfide) from the waste fluid. Based on field experimental and production data, the feasibility of using this cleaning system for storage ponds, taking into account environmental requirements, has been proved. In the technological process of wastewater treatment, it can be recommended as an independent technological line for biological treatment or post-treatment of wastewater.

\section{References}

1. A.A. Bakharev, O.M. Sheveleva et al., Journal of Pharmaceutical Sciences and Research. V. 10. No. 9. P. 2383. (2018)

2. O.V. Kovaleva, N.V. Sannikova, O.V. Shulepova, AgroEcoInfo, No. 3 (37). P. 26. (2019)

3. O.N. Polunina Ecology of Russia: on the way to innovation, an inter-university collection of scientific papers. Issue 7. P. 97-99. (2016)

4. N.V. Sannikova, O.V. Kovaleva, O.V. Shulepova Agri-food policy of Russia, No. 1 (85). P. 13-17. (2019)

5. M. Prisciandaro, F. Vegliò, G. Mazziotti Di Celso Water Research, T. 39. No. 20. P. 5055-5063 (2005)

6. V.A. Blinov, S.N. Burshina, S.V. Kovaleva Probiotics in the food industry and in agriculture (2011)

7. O.A. Kiriy, S.I. Kolesnikov, A.N. Zinchuk Scientific journal KubGAU. No. 83 (09) (2012) 
8. O. Kovaleva, N. Sannikova Advances in Engineering Research. V. 151. 383-390. (2018)

9. N.G. Nasonkina, V.V. Markin Young Researcher Don, No. 4 (7). P. 69-79. (2017)

10. D.I. Eremin, D.V. Eremina Journal of Environmental Management and Tourism. v. 9. No. 3 (27). 599-604. (2018)

11. A. Iglovikov Procedia Engineering. V. 165. P. 800-805. (2016)

12. D.A. Korneva, L.N. Kurov Successes in modern natural sciences, No. 7. P. 129. (2011)

13. K. Oke, S. Neuman, B. Adams Water: chemistry and ecology, No. 6 (60). P. 80-84. (2013)

14. N. Shchegolkova, D. Karyakin et al, Water Science and Technology. v. 78. No 1. P. 69-80 (2018)

15. N.V. Sannikova, O.V. Kovaleva et al., AgroEcoInfo. No. 4. (2018)

16. C.M. Park, K.H. Chu et al., Separation and Purification Reviews.v. 46. No. 3. P. 255272. (2017) 